\title{
On the alleged presence of Halisaurus (Squamata, Mosasauridae) in the latest Cretaceous of the Maastrichtian type area
}

\section{E.W.A. Mulder ${ }^{1}$}

1 Museum Natura Docet, Oldenzaalsestraat 39, NL-7591 GL Denekamp, the Netherlands; e-mail: eric292@gmx.net

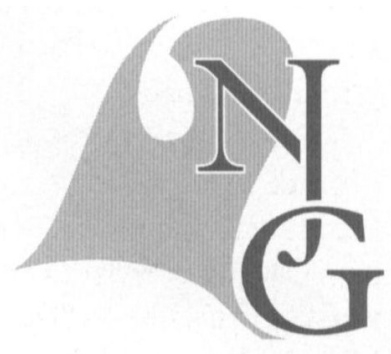

\begin{abstract}
The presence of Halisaurus (Squamata, Mosasauridae) in the uppermost Cretaceous of the Maastrichtian type area, suggested by Lingham-Soliar (1996) on the strength of two partial vertebrae, is questioned. The anatomy of these elements suggests that they pertain not to Halisaurus, but more probably to Plioplatecarpus marshi Dollo, 1882.
\end{abstract}

Keywords: mosasaurs, Maastrichtian type area, New Jersey, vertebrae

\section{Introduction}

It has been noted by several authors (e.g., Bless, 1991; Gallagher, 1993; Jagt \& Kennedy, 1994; Bardet et al., 1998; Kennedy \& Jagt, 1998; Mulder, 1998) that marine deposits of latest Cretaceous age in the Maastrichtian type area and New Jersey share common taxa, both vertebrate and invertebrate. The vertebrate species include mosasaurid squamates, notably Mosasaurus hoffmanni Mantell, 1829 and Plioplatecarpus marshi Dollo, 1882, which are held to be conspecific with $M$. maximus Cope, 1869 and $P$. depressus (Cope, 1869), respectively (Kuypers et al., 1998; Mulder, 1999).

One of 'the rarest and least well-known of the mosasaurs' (Baird, 1986a; Holmes \& Sues, 2000) is the basal taxon Halisaurus platyspondylus Marsh, 1869 , to which until recently only isolated bones from strata of Maastrichtian age in the eastern United States could be referred. Halisaurus platyspondylus is characterised by dorsoventrally compressed vertebral centra. Furthermore, the synapophyses of the cervical and anterior dorsal vertebrae are large in comparison to the breadth of the vertebral centra (Baird, 1986a, b; Holmes \& Sues, 2000) (Fig. 1:1). The synapophyses of the cervicals extend notably below the centra (Holmes \& Sues, 2000). At present, the only other undisputed species of the genus Halisaurus is H. sternbergi (Wiman) from the Santonian (Niobrara Chalk) of Kansas (Holmes \& Sues, 2000).

From the St Pietersberg (Maastricht), LinghamSoliar (1996) reported two 'probable Halisaurus vertebrae', which are housed in the Department of Palaeontology collections at the Natural History Museum (formerly British Museum [Natural History]), London, where they bear registration numbers NHM 42900 and NHM 44822 (see App. 1). Unfortunately, Lingham-Soliar (1996) did not discuss why he referred these specimens to Halisaurus. Therefore, confirmation of the supposed identity and provenance of Halisaurus in the Maastrichtian strata of the type area, as already hinted at by Kuypers et al. (1998), was desirable. Recently, Holmes \& Sues (2000) described from the Severn Formation (Maastrichtian) 

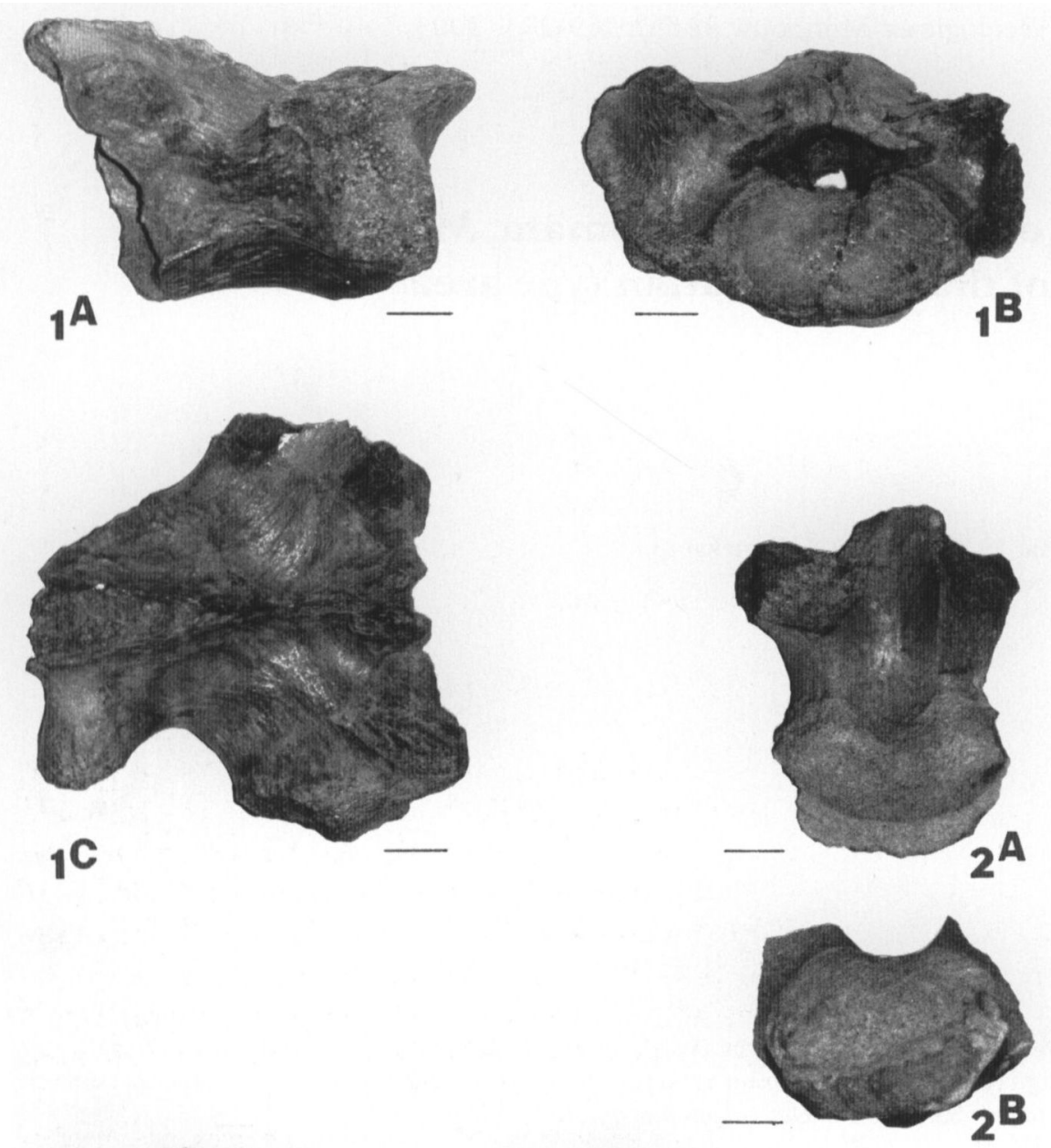

Fig. 1. Mosasaur vertebrae: 1 Halisaurus platyspondylus, dorsal vertebra (ANSP 15316), in right lateral, cotylar, and dorsal views, respectively (compare Baird, 1986b, figs 1B1, 1B2, 1B4); 2 plioplatecarpine mosasaur (Plioplatecarpus(?) sp.), cervical or anterior dorsal vertebra (NHM $42900)$, in dorsal and condylar views, respectively; 3 - Plioplatecarpus sp., cervical vertebra (NHM 44822), in cotylar and left lateral views, respectively. Scale bar equals $10 \mathrm{~mm}$.

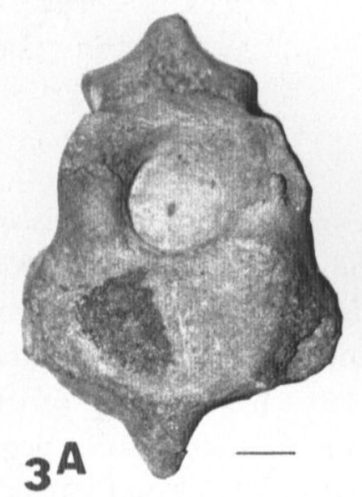

of Maryland the first specimen of $H$. platyspondylus to comprise associated cranial and postcranial material of a single individual. Also, Bardet \& Pereda Superbiola (2002) reported from the Maastrichtian Phosphates of Ruseifa, Jordan, an isolated tooth, referable to the genus as according to these authors.

In the present paper cervical and dorsal vertebrae of the Maryland specimen and a single Halisaurus dorsal vertebra (Academy of Natural Sciences Philadelphia collections, ANSP 15316 (see App. 1; Fig. 1.1)), are compared with NHM 42900, NHM 44822 , as well as with vertebrae of Plioplatecarpus marshi, housed in the collections of Teylers Museum (Haarlem, the Netherlands) (see App. 1).

\section{Description of material}

In their overall appearance and brownish colour the specimens considered do not differ from mosasaurid vertebrae from the Maastrichtian type area. Although Lingham-Soliar (1996, p. 133) stated that NHM 42900 and NHM 44822 were collected at the St Pietersberg (Maastricht), this is not confirmed by the accompanying labels, which merely mention 'Maastricht' as locality.

NHM 42900 is a fragmentary cervical or anterior dorsal vertebra, of which only the centrum is preserved. In the bottom of the neural canal, thus in dorsal position on the centrum, a rectangular foramen is 


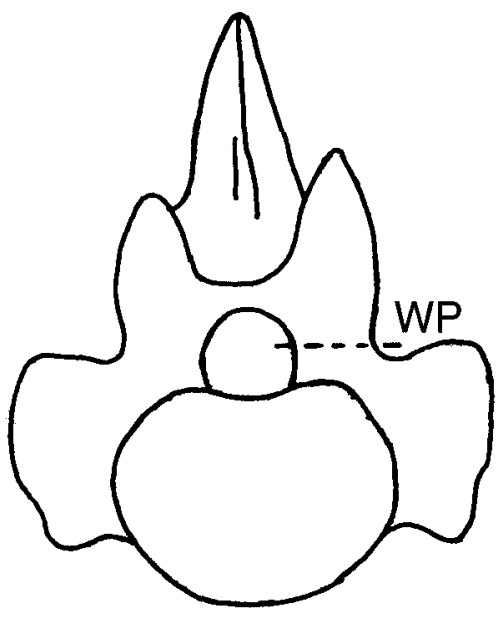

Fig. 2. Schematic cotylar view of a cervical vertebra of Plioplatecarpus; WP - width of pedicel.

visible. The condyle has a reniform outline and is slightly upturned (Fig. 1.2; compare Lingham-Soliar, 1996). The centrum length (as preserved) is $51 \mathrm{~mm}$; the condylar width is $39 \mathrm{~mm}$.

NHM 44822 is a cervical vertebra, of which the neural spine, prezygapophyses and synapophyses are almost completely broken off, or worn away (Fig. 1.3). The cotyle looks eroded. The bottom of the neural canal is not visible, because the canal itself is filled with indurated matrix. Centrum length: $44 \mathrm{~mm}$; vertebral height: $62 \mathrm{~mm}$; width of neural canal 12.5 $\mathrm{mm}$; width of pedicels: $10.5 \mathrm{~mm}$ (see also Fig. 2).

\section{Discussion}

In cervicals and anterior dorsals of Halisaurus platyspondylus, the pedicels are wider than the neural canal (Fig. 1.1) (Holmes \& Sues, 2000). This phenomenon is quantified in Table 1 (Fig. 2).

In NHM 44822 the ratio between the width of the neural canal and the width of the pedicels differs from the same ratios in the cervicals of Halisaurus (see Table 1). The ratio in NHM 44822 is similar to that in Plioplatecarpus marshi. Here, the width of the pedicels of the cervicals and anterior dorsals comes close to the width of the neural canal (see Table 2).
Table 1. Ratio between width of the neural canal (WNCA) and width of the pedicels (WP; see also Fig. 2) of cervical vertebrae of Halisaurus platyspondylus, USNM 442450 (based on Holmes \& Sues, 2000, fig. 7), as compared to WNCA/WP of NHM 44822.

\begin{tabular}{cl}
\hline Vertebra & WNCA/WP \\
\hline USNM 442450 & \\
C3 & 0.73 \\
C4 & 0.64 \\
C5 & 0.65 \\
C6 & 0.52 \\
C7 & 0.60 \\
NHM 44822 & 1.19 \\
\hline
\end{tabular}

NHM 44822 shows a strong resemblance to cervicals of the last-mentioned species (Fig. 1.3). Halisaurine characters as mentioned earlier cannot be observed in the fragmentary synapophyses of NHM 44822.

Preservation of the other specimen, NHM 42900, is so fragmentary that no 'halisaurine' character can be observed. However, the rectangular foramen on the centrum suggests plioplatecarpine affinities. Furthermore, the condyle in this vertebra is not nearly dorsoventrally compressed enough for it to be assigned to Halisaurus, but is similar in proportions to a cervical vertebra of Plioplatecarpus (compare Holmes, 1996; Holmes \& Sues, 2000).

It is therefore concluded, that the presence of $\mathrm{Hal}$ isaurus in the latest Cretaceous of the Maastrichtian type area is not supported by either NHM 42900 or NHM 44822. The common occurrence of Plioplatecarpus marshi in the uppermost Cretaceous of the Maastrichtian type area has been observed ever since Dollo's brief description of the species (Dollo, 1882).

\section{Acknowledgements}

I wish to thank Professor G.J. Boekschoten (Vrije Universiteit Amsterdam) and Dr J.W.M. Jagt (Natuurhistorisch Museum Maastricht), who critically read the typescript and made useful suggestions. I acknowledge the valuable comments made by Dr R.B. Holmes (Canadian Museum of Nature, Ottawa) and an anonymous reviewer. Furthermore, I extend my

Table 2. Measurements (in $\mathrm{mm}$ ) of studied vertebrae of Plioplatecarpus marshi from the Maastrichtian type area; CL - centrum length; CW centrum width;WNCA - width of neural canal (measured at condyle); WP - width of pedicel.

\begin{tabular}{llllll}
\hline Vertebra & CL & CW & WNCA & WP & WNCA/WP \\
\hline TM 11226 & 50.5 & 38.5 & 14.2 & 11.8 & 1.20 \\
TM 11318 & 53.5 & 40.8 & 14.2 & 11.5 & 1.07 \\
TM 11331 & 52.3 & 42.4 & 15 & 12.3 & 1.30 \\
TM 17246 & 48 & 37.8 & & 1.21 & \\
\hline
\end{tabular}


best thanks to the following people for allowing access to museum collections and for assistance in various ways: S. Chapman (The Natural History Museum, London), Dr E. Benamy and E. Gilmore (both Academy of Natural Sciences Philadelphia) and J. van Veen (Teylers Museum, Haarlem).

\section{Appendix 1. Material studied}

\section{Academy of Natural Sciences Philadelphia (ANSP)}

ANSP 15316 - Halisaurus platyspondylus, dorsal vertebra; Phoebus Landing, North Carolina; Maastrichtian. From the same locality there is another, much smaller specimen bearing the same registration number.

\section{The Natural History Museum, London (NHM)}

NHM 42900 - plioplatecarpine mosasaur, Plioplatecarpus(?) sp., fragmentary cervical or anterior dorsal vertebra; Maastrichtian type area (ex Van Breda Colln according to label). Specimen not listed in Lydekker (1888).

NHM 44822 - Plioplatecarpus sp., cervical vertebra; Maastrichtian type area. According to Lydekker (1888, p. 273), 'presented by B. Bright Esq., 1873', and listed as Clidastes $\mathrm{sp}$.

\section{Teylers Museum, Haarlem (TM)}

TM 11226 - Plioplatecarpus marshi, anterior dorsal vertebra; St Pietersberg, Maastricht; Late Maastrichtian (Maastricht Formation), ex P. Camper Colln.

TM 11318 - Plioplatecarpus marshi, anterior dorsal vertebra; St Pietersberg, Maastricht; Late Maastrichtian ('Craie à silex gris' [= Emael Member], Maastricht Formation).

TM 11331 - Plioplatecarpus marshi, fragmentary posterior cervical vertebra; St Pietersberg, Maastricht; Late Maastrichtian ('Craie à silex gris' [= Emael Member], Maastricht Formation), ex Henckelius Colln.

TM 17246 - Plioplatecarpus marshi, anterior dorsal vertebra; St Pietersberg, Maastricht; Late Maastrichtian (Maastricht Formation).

\section{References}

Baird, D., 1986a. Upper Cretaceous reptiles from the Severn Formation of Maryland. The Mosasaur 3: 63-85.

Baird, D., 1986b. Halisaurus and Prognathodon, two uncommon mosasaurs from the Upper Cretaceous of New Jersey. The Mosasaur 3: 37-45.

Bardet, N., Jagt, J.W.M., Kuypers, M.M.M. \& Dortangs, R.W., 1998. Shark tooth marks on a vertebra of the mosasaur Plioplatecarpus marshi from the Late Maastrichtian of Belgium. Publicaties van het Natuurhistorisch Genootschap in Limburg 41: 5255.

Bardet, N. \& Pereda Superbiola, X., 2002. Marine reptiles from the Late Cretaceous Phosphates of Jordan: paleobiogeographical implications. Geodiversitas 24(4): 831-839.

Bless, M.J.M., 1991. Immigranten uit Noord-Afrika en Zuid-Europa in de Laat-Krijtzee van Noord-Europa. Een samenspel van warme zeestromen, verdwenen barrières en gunstige milieufactoren. Grondboor en Hamer 45: 73-83.

Dollo, L., 1882. Note sur l'ostéologie des Mosasauridae [sic]. Bulletin du Musée royal d'Histoire naturelle de Belgique 1: 55-74.

Gallagher, W.B., 1993. The Cretaceous/Tertiary Mass Extinction Event in the Northern Atlantic Coastal Plain. The Mosasaur 5: 75-154.

Holmes, R.B., 1996. Plioplatecarpus primaevus (Mosasauridae) from the Bearpaw Formation (Campanian, Upper Cretaceous) of the North American Western Interior Seaway. Journal of vertebrate Paleontology 16(4): 673-687.

Holmes, R.B. \& Sues, H.-D., 2000. A partial skeleton of the basal mosasaur Halisaurus platyspondylus from the Severn Formation (Upper Cretaceous: Maastrichtian) of Maryland. Journal of Paleontology 74(2): 309-316.

Jagt, J.W.M. \& Kennedy, W.J., 1994. Feletzkytes dorfi Landman \& Waage 1993, a North American ammonoid marker from the lower Upper Maastrichtian of Belgium, and the numerical age of the Lower/Upper Maastrichtian boundary. Neues Jahrbuch für Geologie und Paläontologie Monatshefte 1994/4: 239-245.

Kennedy, W.J. \& Jagt, J.W.M., 1998. Additional Late Cretaceous ammonite records from the Maastrichtian type area. Bulletin de l'Institut royal des Sciences naturelles de Belgique, Sciences de la Terre 68: 155-176.

Kuypers, M.M.M., Jagt, J.W.M., Peeters, H.H.G., de Graaf, D.T., Dortangs, R.W., Deckers, M.J.M., Eysermans, D., Janssen, M.J. \& Arpot, L., 1998. Laat-kretaceische mosasauriers uit Luik-Limburg: nieuwe vondsten leiden tot nieuwe inzichten. Publicaties van het Natuurhistorisch Genootschap in Limburg 41: 4-47.

Lingham-Soliar, T., 1994. The Mosasaur Plioplatecarpus (Reptilia, Mosasauridae) from the Upper Cretaceous of Europe. Bulletin de l'Institut royal des Sciences naturelles de Belgique, Sciences de la Terre 64: 177-211.

Lingham-Soliar, T., 1996. The first description of Halisaurus (Reptilia Mosasauridae) from Europe, from the Upper Cretaceous of Belgium. Bulletin de l'Institut royal des Sciences naturelles de Belgique, Sciences de la Terre 66: 129-136.

Lydekker, R.A., 1888. Catalogue of the fossil Reptilia and Amphibia in the British Museum (Natural History), 1. Ornithosauria, Crocodilia, Dinosauria, Squamata, Rhynchocephalia and Proterosauria. British Museum (Natural History) (London): xxviii + 309 pp.

Mulder, E.W.A., 1998. Thoracosaurine vertebrae (Crocodylia; Crocodylidae) from the Maastrichtian type area. Proceedings of the Koninklijke Nederlandse Akademie van Wetenschappen 100(1997): 161-170.

Mulder, E.W.A., 1999. Transatlantic latest Cretaceous mosasaurs 
(Reptilia, Lacertilia) from the Maastrichtian type area and New Jersey. Geologie en Mijnbouw 78: 281-300.

Wiman, C., 1920. Some reptiles from the Niobrara Group in Kansas. Bulletin of the Geological Institute, University of Uppsala 18: 11-18. 